\title{
EVALUATION OF MALNUTRITION STATUSES IN SYSTOLIC HEART FAILURE PATIENTS
}

\author{
Irmak İrem Özyiğit ${ }^{1}$, Beliz Koçyiğit ${ }^{1}$, Begüm Söyleyici ${ }^{1}$, Fatih Mehmet Uçar ${ }^{2}$
}

${ }^{1}$ Trakya University School of Medicine, Edirne, TURKEY

${ }^{2}$ Department of Cardiology, Trakya University School of Medicine, Edirne, TURKEY

\section{ABSTRACT}

Aims: The aim of this study is to determine the malnutrition statuses of patients with systolic heart failure in Trakya University Hospital and Edirne Sultan $1^{\text {st }}$ Murat State Hospital.

Methods: Mini Nutritional Assessment was used to determine the patients' malnutrition statuses. In addition, patients' transthoracic echocardiography results, biochemistry tests, hemograms, medications and habits were evaluated with patients' nutritional scores. One-way ANOVA and Kruskal-Wallis tests were used for comparing the results and Pearson $\chi 2$ test and Fischer's exact test were used to obtain categorical data.

Results: The total number of subjects in the study was 66 (61 patients from Trakya University Hospital; 5 patients from Edirne Sultan $1^{\text {st }}$ Murat State Hospital). The mean age of all subjects was $65.3 \pm 11.1$. Out of all patients, 17 of them were female, while 49 of them were male. The mean Mini Nutrition Assessment score was 21.9 \pm 4.7 . In total, 34 patients had an adequate nutritional status, 25 patients were at risk of malnutrition and 7 patients were malnourished.

Conclusion: Although malnourished patients were detected, well - nourished patients were higher. Therefore, it could be said that patients with heart failure are conscious of their health and diet. It is crucial for the health care providers to maintain giving advices on healthy living and nutrition to keep this elderly population well-nourished.

Keywords: Nutrition assessment, systolic heart failure, malnutrition

\section{INTRODUCTION}

Heart failure (HF) is a pathophysiological condition defined as the failure of the heart to supply the requirements of the metabolizing tissues under normal cardiac pressures due to an abnormality in cardiac function (1, 2 ). HF is a major health problem which is a leading and increasing cause of mortality and morbidity around the world (3). Broadly, the prevalence of HF in the western world is at $1-2 \%$ and the incidence accounts for $5-10$ per 1000 people per year (4). Symptoms of HF include fatigue, dyspnea, limited exercise tolerance and accumulation of concomitant fluid. With the aging population, higher portion of individuals such as people with hypertension, diabetes mellitus and obesity are exposed to the possibility of developing HF (2).

Clinically, HF patients can be divided into two categories; patients with $\mathrm{HF}$ with preserved $(\geq 50 \%)$ ejec- tion fraction (HFpEF) and patients with HF with reduced left ventricular ejection fraction $(\mathrm{HFrEF})(\leq 40 \%)$. Leastwise, half of the HF patients have a reduced ejection fraction (5).

Heart failure with reduced left ventricular ejection fraction is caused by an initial injury or disease state, which can be cardiovascular-originated or originally include other organ systems followed by the evolution of secondary cardiovascular abnormalities that lead to reduced ventricular contraction. With the most important risk factor for HFrEF is being hypertension, other cardiovascular etiologies of HFrEF are myocardial infarction, cardiomyopathies, myocarditis, cardiac infection and valvular diseases. Extra-cardiac causes of HF$\mathrm{rEF}$ are systemic diseases, endocrine etiologies, high in take of illicit drugs and alcohol, side effects of chemotherapy treatment. When it comes to stable patients with pre-existing HFrEF, various factors can accelerate 
clinical decompensation, worsen the symptoms thus create the need for hospitalization of patients. These factors consist of ischemia, arrhythmia, infection, failing to comply with medications and dietary restrictions (2).

According to World Health Organization (WHO) malnutrition is defined as excesses, imbalances, inadequacies in a person's intake of energy and/or nourishments (6). WHO also states that the term malnutrition covers two groups of conditions; one being undernutrition and the other one being overweight, obesity and noncommunicable diseases related to diet. Undernutrition includes wasting, stunting, underweight and micronutrient insufficiencies or deficiencies. Examples for diet-related noncommunicable diseases can be diabetes, stroke, cancer and heart disease (6).

Intestinal edema, anorexia, malabsorption, rise of basal metabolism ratio and the increase in energy and nutrition needs of the heart lead to malnutrition among HF patients (7). Moreover, pharmacological therapy can also lead to insufficient energy and nutrition intake by causing loss of appetite that (8). In conclusion, malnutrition induces intensified edema, inflammation, neurohormonal activity and is highly associated with adverse prognosis among HF patients (7).

Malnutrition is often seen among patients with HF and it is associated with the lower quality of life and increased risk of mortality $(9,10)$. Despite increasing evidence concerning the crucial role of micronutrient deficiencies in chronic HF, the HF guidelines have not yet declared definitive nutritional strategies and the number of clinical research inspecting the effects of micronutrient supplementations on the prevention of malnutrition are still confined. Therefore, to be able to assess generally recognized nutritional strategies to improve the functional capacity and quality of life more researches are needed to be carried out regarding malnutrition of HF patients (9).

The aim of this study is to determine the malnutrition statuses of systolic heart failure patients evaluated between 15 January - 10 February 2019 in Trakya University Medical Research and Practice Hospital and Edirne Sultan $1^{\text {st }}$ Murat State Hospital by using the results of Mini Nutritional Assessment $\left(\mathrm{MNA}^{\circledR}\right)$, patients' transthoracic echocardiography, biochemistry tests, hemograms, medications and habits (11).

\section{MATERIAL AND METHODS}

This study was approved by the Scientific Research Ethics Committee of Trakya University Medical Faculty. Informed consent was obtained from all of the patients. In this cross-sectional and descriptive study, the study population was composed of patients over 18 years old who were diagnosed with systolic heart failure with $\mathrm{EF} \leq 40 \%$, and applied to the cardiology department of Trakya University Hospital, and Edirne Sultan $1^{\text {st }}$ Murat State Hospital between 15th of January - 10th of February, 2019. Seventy patients were asked to fill the $\mathrm{MNA}^{\oplus}$ survey to evaluate their anthropometric characteristics, general status, dietary habits, and subjective assessments. After data collection, 66 patients (61 patients from Trakya University Hospital, 5 patients from Edirne Sultan $1^{\text {st }}$ Murat State Hospital) were included in the study. The rest were excluded because of inconsistent and incomplete data. $\mathrm{MNA}^{\oplus}$ consists of 18 questions, and four parts to determine patients' nutritional status. If malnutrition indicator score is less than 17 points, the patient is malnourished. 17 to 23.5 points indicate a risk of malnutrition, and 24 to 30 points indicate that the patient is in normal nutritional status (11).

\section{Mini Nutritional Assessment}

A. Has food intake declined over the past 3 months due to loss of appetite, digestive problems, chewing or swallowing difficulties?

(0: Severe decrease in food intake. / 1: Moderate decrease in food intake. / 2: No decrease in food intake.)

B. Weight loss during the last 3 months

(0: Weight loss greater than $3 \mathrm{~kg}$ (6.6lbs). / 1: Does not know. / 2: Weight loss between 1 and $3 \mathrm{~kg}$ (2.2 and 6.6 lbs). / 3 : No weight loss.)

C. Mobility

(0: Bed or chair bound. / 1: Able to get out of bed / chair but does not go out. / 2: Goes out.)

D. Has suffered psychological stress or acute disease in the past 3 months?

(0: Yes. / 2: No.)

E. Neuropsychological problems

(0: Severe dementia or depression. / 1: Mild dementia. /

2: No psychological problems.)

F. Body Mass Index (BMI) = weight in $\mathrm{kg} /$ (height in m) 2

(0: BMI less than 19. / 1: BMI 19 to less than 21. / 2: BMI 21 to less than 23. / 3: BMI 23 or greater.)

G. Lives independently (not in nursing home or hospital)

(1: Yes. / 0: No.) 
H. Takes more than 3 prescription drugs per day

(0: Yes. / 1: No.)

I. Pressure sores or skin ulcers

(0: Yes. / 1: No.)

J. How many full meals does the patient eat daily?

(0: 1 meal. / 1: 2 meals. / 2: 3 meals.)

K. Selected consumption markers for protein intake

At least one serving of dairy products (milk, cheese, yoghurt) per day (Yes / No)

Two or more serving of legumes or eggs per week (Yes / No)

Meat, fish or poultry every day (Yes / No)

( 0 : If 0 or 1 yes. / 0.5: If 2 yes. / 1: If 3 yes.)

L. Consumes two or more servings of fruit or vegetables per day?

(0: No. / 1: Yes.)

M. How much fluid (water, juice, coffee, tea, milk...) is consumed per day?

(0: Less than 3 cups. / 0.5: 3 to 5 cups. / 1: More than 5 cups.)

N. Mode of feeding

(0: Unable to eat without assistance. / 1: Self-fed with some difficulty. / 2: Self-fed without any problem.)

O. Self view of nutritional status

(0: Views self as being malnourished. / 1: Is uncertain of nutritional state. / 2: Views self as having no nutritional problem.)

P. In comparison with other people of the same age, how does the patient consider his / her health status?

(0: Not as good. / 0.5: Does not know. / 1: As good. / 2.0: Better.)

Q. Mid-arm circumference (MAC) in $\mathrm{cm}$

(0: MAC less than 21. / 0.5: MAC 21 to 22. / 1: MAC greater than 22.)

R. Calf circumference (CC) in $\mathrm{cm}$

(0: CC less than 31. / 1: CC 31 or greater.)

In addition to the $\mathrm{MNA}^{\circ}$, patients' medications were recorded according to the following classes: acetylsalicylic acid, angiotensin - converting enzyme inhibitors angiotensin 2 receptor blocker, $\beta$-blockers, aldosterone antagonists, statins, diuretics, antiarrhythmics, anticoagulants, sacubitril/valsartan. Findings of echocardiography that included their left ventricular enddiastolic diameter (LVEDD) and ejection fraction (EF) values were collected from the patients' files of Trakya University Medical Faculty and Edirne Sul$\tan 1^{\text {st }}$ Murat State Hospital. Patients' habit of smoking, sex, age, weight $(\mathrm{kg})$, and height $(\mathrm{cm})$ were recorded by their verbal statement. Pre-prandial blood glucose, urea, creatinine, aspartate aminotransferase (AST), alanine aminotransferase (ALT), low density lipoprotein
(LDL), high density lipoprotein (HDL), triglyceride (TG), hemoglobin, hematocrit (HCT), albumin, white blood cell (WBC), neutrophile, lymphocyte, platelet (PLT), c-reactive protein (CRP) levels and history of patients' chronic diseases - if any [hypertension (HT), hyperlipidemia (HL), diabetes mellitus (DM)] were recorded from the archives of Trakya University Hospital and Edirne Sultan $1^{\text {st }}$ Murat State Hospital through patients' medical record numbers to determine patients' nutritional status.

After data collection, statistical analysis was carried out with IBM SPSS Statistics for Windows, Version 22.0. Armonk, NY: IBM Corp. A p-value of $<0.05$ was set for statistically significance. As descriptive statistics, mean \pm standard deviation or median with 25 th- 75 th percentiles were used for continuous variables. Categorical variables were expressed as numbers and percentages. Compatibility of continuous variables to normal dissemination was evaluated with the Sharipo Wilk test. For comparing the groups, One-way ANOVA and Kruskal-Wallis tests were used. Pearson $\chi 2$ test and Fischer's exact test were used to achieve categorical data.

\section{RESULTS}

The total number of subjects in the study was 66 . The mean age of all subjects was $65.3 \pm 11.1$. Out of all patients, 17 of them were female, while 49 of them were male. The mean age of female subjects was $67.9 \pm 11.2$, whereas the mean age of male subjects was $63.9 \pm 10.9$. Taking into consideration the MNA results, the mean score was $21.9 \pm 4.7$. Our MNA results also portray that 7 female and 27 male subjects had an adequate nutritional status, 7 female and 18 male subjects were at risk of malnutrition, 3 female and 4 male subjects were malnourished. The mean MNA score for females was 21.5 \pm 5.04 , while the mean score for males was $23.3 \pm 3.9$. Evaluation of MNA questions and subjects' answers according to groups are presented at Table 1 . The difference of subjects' answers to questions A, B, D, E, O among groups were found to be statistically significant $(\mathrm{p}<0.001)$. Biochemical, echocardiography parameters and medications of patients can be observed at Table 2 . Statistically significant difference was found at platelet counts between groups $(\mathrm{p}=0.045)$. 
Table 1: Evaluation of MNA questions according to groups.

\begin{tabular}{|c|c|c|c|c|c|c|c|}
\hline \multirow{2}{*}{ Questions } & \multicolumn{2}{|c|}{$\begin{array}{l}\text { Adequate nutritional } \\
\text { status }(n=34)\end{array}$} & \multicolumn{2}{|c|}{$\begin{array}{l}\text { Risk of malnutrition } \\
\qquad(n=25)\end{array}$} & \multicolumn{2}{|c|}{$\begin{array}{c}\text { Malnourished } \\
(n=7)\end{array}$} & \multirow{2}{*}{ Pvalue } \\
\hline & $\begin{array}{l}\text { The option } \\
\text { chosen the } \\
\text { most }\end{array}$ & $n(\%)$ & $\begin{array}{l}\text { The option } \\
\text { chosen the most }\end{array}$ & $n(\%)$ & $\begin{array}{l}\text { The option } \\
\text { chosen the most }\end{array}$ & $n(\%)$ & \\
\hline$A$ & $\begin{array}{l}\text { no decrease in } \\
\text { food intake }\end{array}$ & $33(97.1)$ & $\begin{array}{l}\text { no decrease in } \\
\text { food intake }\end{array}$ & $17(68)$ & $\begin{array}{l}\text { severe decrease } \\
\text { in food intake }\end{array}$ & $5(71)$ & 0.0001 \\
\hline$B$ & no weight loss & $26(76.5)$ & no weight loss & $13(52)$ & $\begin{array}{l}\text { weight loss } \\
\text { greater than } 3 \mathrm{~kg}\end{array}$ & $6(85.7)$ & 0.0001 \\
\hline C & goes out & $31(91.2)$ & goes out & $19(76)$ & goes out & $3(42.9)$ & 0.004 \\
\hline$D$ & no & $3(88.2)$ & no & $13(52)$ & yes & $7(100)$ & 0.0001 \\
\hline$E$ & $\begin{array}{l}\text { no psychological } \\
\text { problems }\end{array}$ & $31(91.2)$ & $\begin{array}{l}\text { no psychological } \\
\text { problems }\end{array}$ & $16(64)$ & $\begin{array}{l}\text { mild/severe } \\
\text { dementia or } \\
\text { depression }\end{array}$ & $6(85.8)$ & 0.0001 \\
\hline G & yes & $34(100)$ & yes & $22(88)$ & yes & $7(100)$ & 0.124 \\
\hline$H$ & yes & $29(85.3)$ & yes & $23(92)$ & yes & $7(100)$ & 0.614 \\
\hline$I$ & no & $34(100)$ & no & $23(92)$ & no & $5(71.4)$ & 0.012 \\
\hline$J$ & 3 meals & $27(79.4)$ & 3 meals & $22(88)$ & 3 meals & $4(57.1)$ & 0.106 \\
\hline$K$ & if 2 yes & $26(76.5)$ & if 2 yes & $15(60)$ & if 0 or 1 yes & $4(57.1)$ & 0.007 \\
\hline$L$ & no & $27(79.4)$ & no & $15(60)$ & no & $5(71.4)$ & 0.302 \\
\hline$M$ & more than 5 cups & $26(79.5)$ & more than 5 cups & $16(64)$ & 3 to 5 cups & $3(42.9)$ & 0.317 \\
\hline$N$ & $\begin{array}{l}\text { self-fed without } \\
\text { any problem }\end{array}$ & $33(97.1)$ & $\begin{array}{l}\text { self-fed without } \\
\text { any problem }\end{array}$ & $24(96)$ & $\begin{array}{l}\text { self-fed without } \\
\text { any problem }\end{array}$ & $5(71.4)$ & 0.058 \\
\hline$O$ & $\begin{array}{l}\text { views self as } \\
\text { having no } \\
\text { nutritional } \\
\text { problem }\end{array}$ & $29(85.3)$ & $\begin{array}{l}\text { views self as } \\
\text { having no } \\
\text { nutritional } \\
\text { problem }\end{array}$ & $10(40)$ & $\begin{array}{l}\text { views self as being } \\
\text { malnourished }\end{array}$ & $5(71.4)$ & 0.0001 \\
\hline$p$ & As good & $12(35.3)$ & Not as good & $12(48)$ & Not as good & $6(85.7)$ & 0.024 \\
\hline$Q$ & $\begin{array}{l}\text { Mid-arm } \\
\text { circumference } \\
\text { greater than } 22 \\
\mathrm{~cm}\end{array}$ & $31(91.2)$ & $\begin{array}{l}\text { Mid-arm } \\
\text { circumference } \\
\text { greater than } 22 \\
\mathrm{~cm}\end{array}$ & $23(92)$ & $\begin{array}{l}\text { Mid-arm } \\
\text { circumference } \\
\text { greater than } 22 \mathrm{~cm}\end{array}$ & $5(71.4)$ & 0.193 \\
\hline$R$ & $\begin{array}{l}\text { Calf } \\
\text { circumference } 31 \\
\mathrm{~cm} \text { or greater }\end{array}$ & $34(100)$ & $\begin{array}{l}\text { Calf } \\
\text { circumference } 31 \\
\mathrm{~cm} \text { or greater }\end{array}$ & $24(96)$ & $\begin{array}{l}\text { Calf } \\
\text { circumference } 31 \\
\mathrm{~cm} \text { or greater }\end{array}$ & $5(71.4)$ & 0.012 \\
\hline
\end{tabular}


Table 2: Biochemical, echocardiography parameters and medications of patients.

\begin{tabular}{|c|c|c|c|c|}
\hline & $\begin{array}{l}\text { Adequate } \\
\text { nutritional status } \\
\text { MNA }>24(n=34)\end{array}$ & $\begin{array}{l}\text { Risk of } \\
\text { malnutrition } \\
\text { MNA 17-23.5 } \\
(n=25)\end{array}$ & $\begin{array}{l}\text { Malnourished } \\
\text { MNA<17 } \\
(n=7)\end{array}$ & P value \\
\hline Age (years) & $64.5(58-67.2)$ & $66(58-74)$ & $68(65-69)$ & 0.145 \\
\hline Male $n,(\%)$ & $27(79.4)$ & $18(72)$ & $4(57.1)$ & 0.447 \\
\hline$B M I, k g / m^{2}$ & $29.1 \pm 4.2$ & $27.5 \pm 4$ & $25.4 \pm 4.1$ & 0.081 \\
\hline Hypertension $n,(\%)$ & $24(70.6)$ & $17(68)$ & $6(85.7)$ & 0.793 \\
\hline Hyperlipemia n, (\%) & $11(32.4)$ & $8(32)$ & $1(14.3)$ & 0.746 \\
\hline Diabetes $n,(\%)$ & $10(29.4)$ & $12(48)$ & $3(42.9)$ & 0.333 \\
\hline Smoking $n,(\%)$ & $6(17.6)$ & $8(32)$ & $2(28.6)$ & 0.428 \\
\hline Ejection Fraction (\%) & $31.5(29-35)$ & $32(30-35.5)$ & $30(23-34)$ & 0.393 \\
\hline LVEDD $(\mathrm{mm})^{\text {*d }}$ & $60.5(56-67.7)$ & $61.5(56-67.5)$ & $53(50-64)$ & 0.416 \\
\hline Glucose $(m g / d l)^{b}$ & $112(98-130.5)$ & $122.5(106-206.7)$ & $152(103-209)$ & 0.154 \\
\hline Urea $(m g / d l)^{b}$ & $40(33.5-48.5)$ & $42.5(33-54.2)$ & $101(42-116)$ & 0.098 \\
\hline Creatinine $(m g / d l)^{a}$ & $1(0.8-1.1)$ & $1(0.8-1.2)$ & $1.3(0.8-3.2)$ & 0.254 \\
\hline $\operatorname{AST}(U / t)^{b}$ & $21.5(16-25)$ & $24(18-28)$ & $23(18-60)$ & 0.239 \\
\hline $\operatorname{ALT}(U / l t)^{b}$ & $15(10-18.5)$ & $15(12-23)$ & $23(13-63)$ & 0.181 \\
\hline $\operatorname{LDL}(m g / d l)^{c}$ & $107.4 \pm 26.8$ & $112 \pm 29.4$ & $109.8 \pm 38.2$ & 0.843 \\
\hline$H D L(m g / d l)^{c}$ & $35(32.7-40.2)$ & $35.5(28.2-42.2)$ & $31(17-46.8)$ & 0.793 \\
\hline$T G(m g / d l)^{*}$ & $148.5(98.7-185)$ & $116.5(65.7-149)$ & $96.5(63.2-165)$ & 0.072 \\
\hline Hemoglobin $(m g / d l)^{a}$ & $12.9 \pm 1.8$ & $12.5 \pm 1.9$ & $12.4 \pm 1.7$ & 0.659 \\
\hline $\operatorname{HCT}(\%)^{* a}$ & $38.5 \pm 4.4$ & $37.9 \pm 5.7$ & $38.2 \pm 5.6$ & 0.901 \\
\hline PLT $10^{3} / \mathrm{mm}^{3}$ *a & $210(181-259.7)$ & $222(171.2-297.7)$ & $155(126-178)$ & 0.045 \\
\hline$W B C 10^{3} / m l^{* a}$ & $8.6(7-10)$ & $8.2(7-9.8)$ & $6.9(5.4-8.4)$ & 0.318 \\
\hline Neutrophil (\%)" & $62 \pm 12.3$ & $65.6 \pm 7.8$ & $70.6 \pm 13.5$ & 0.133 \\
\hline Lymphocytes/ $\mu l^{\text {a }}$ & $2 \pm 0.6$ & $2 \pm 1.1$ & $1.4 \pm 0.6$ & 0.179 \\
\hline $\operatorname{CRP}(m g / l)^{c}$ & $0.6(0.4-1.6)$ & $0.8(0.3-1.5)$ & $7.5(1-7.9)$ & 0.057 \\
\hline $\operatorname{Albumin}(\mathrm{g} / \mathrm{dl})^{e}$ & $3.7(3.3-4.2)$ & $3.5(3.1-4.1)$ & $3(2.7-3.4)$ & 0.070 \\
\hline \multicolumn{5}{|l|}{ Medications } \\
\hline $\operatorname{ASA} n,(\%)^{* a}$ & $19(55.9)$ & $13(54.2)$ & $2(28.6)$ & 0.458 \\
\hline $\operatorname{ACEI} n,(\%)^{* a}$ & $15(44.1)$ & $11(45.8)$ & $3(42.9)$ & 1.000 \\
\hline$A R B n,(\%) * a$ & $1(2.9)$ & $5(20.8)$ & $0(0)$ & 0.085 \\
\hline Beta-blocker $n,(\%)^{a}$ & $33(97.1)$ & $22(91.7)$ & $7(100)$ & 0.692 \\
\hline Ald-antg $n,(\%)^{* a}$ & $18(52.9)$ & $14(58.3)$ & $4(57.1)$ & 0.935 \\
\hline Statin $n,(\%)^{a}$ & $16(47.1)$ & $13(54.2)$ & $1(14.3)$ & 0.202 \\
\hline Diuretic $n,(\%)^{a}$ & $21(61.8)$ & $18(75)$ & $5(71.4)$ & 0.643 \\
\hline Antiarrhythmics $n,(\%)^{a}$ & $5(14.7)$ & $3(12.5)$ & $0(0)$ & 0.870 \\
\hline Anticoagulant $n,(\%)^{a}$ & $15(44.1)$ & $7(29.2)$ & $4(57.1)$ & 0.312 \\
\hline $\begin{array}{l}\text { Sacubitril/Valsartan } \\
n,(\%)^{\star}\end{array}$ & $3(8.8)$ & $3(12.5)$ & $2(28.6)$ & 0.339 \\
\hline
\end{tabular}

${ }^{*}$ LVEDD: left ventricular end-diastolic diameter, TG: Triglycerides, HTC: Hematocrit, PLT: Platelets, WBC: White blood cells, CRP: C-reactive protein, ASA: Acetylsalicylic acid, ACEI: Angiotensin-converting-enzyme inhibitor, ARB: Angiotensin II receptor blocker, Ald-antg: Aldosterone antagonist,

$a$ : one missing data, $b$ : two missing data, $c$ : four missing data, $d$ : five missing data, e: eight missing data As descriptive statistics, quantitative data were expressed as mean \pm standard deviation or median (25th-75th percentiles) and qualitative data were expressed as numbers (percentages). 


\section{DISCUSSION}

Heart failure is a worldwide health problem among the elderly population and mainly appears with reduced ejection fraction that causes reduced living standards and morbidity (2). Due to this condition, heart is inoperative to supply the requirements of the tissues to maintain normal cardiac function (1).

In line with previous studies, risk factors such as obesity, hypertension, and diabetes mellitus are seen frequently among HF patients (1). In our study the result of body - mass index was lower in undernourished patients, compared to the other groups, but there was not a significant difference since the malnourished group was already in normal weight range. According to the local studies, body mass index may cause misdirection because it does not reflect weight loss completely (12). In our findings, when body mass index is compared to weight loss in the last 3 months, in the malnourished group, there is a significant weight loss greater than 3 $\mathrm{kg}(\mathrm{p}=0.0001)$, even though they are in normal weight range. Additionally, the comorbid diesases of our patients' hypertension and diabetes were consistent with the study of Bonilla-Palomas et al. (13) which was conducted on 208 patients.

In our study, although there was no significant difference in smoking rate among all groups $(\mathrm{p}=0.428)$, quitting smoking is important to reduce the risk of smoking-related cardiovascular diseases (14).

According to the literature, the majority of the HF patients are classified as at risk of malnutrition $(12,13)$. Our study revealed that $51.5 \%$ of the patients were in adequate nutritional status. As for the reason, it is thought that patients with heart failure are cautious about their health. Nevertheless in our study the percentages of the malnourished patients are in accordance with the literature $(12,13)$.

Our results demonstrated that the percentage of medication usage was higher in well-nourished group for ASA and antiarrhythmic drugs. Beta-blocker was prescribed for all malnourished patient group $(n=7)$, meanwhile ARB and antiarrhythmic drugs were not in their drug therapy. A similar conclusion was reached by Bonilla-Palomas et al. (13) in beta-blocker usage but they indicate that there was no prognostic benefit specified with this drug.
In this study, the main limitation was the patient profile that we conducted the questionnaire. It could be argued that a higher percentage of the malnutrition and the risk of malnutrition levels could be obtained if this survey would be performed on severely ill patients, but these severe patients have refused were incapable of attending to our survey.

High in reliability and validity, $\mathrm{MNA}^{\oplus}$ was originally developed for the elderly (mean age $73 \pm 10.1$ ) patients , and the mean age of our subjects was $65.3 \pm 11.1$ which was another limitation for our study (13). In addition, in our study, no significant difference was found in the measure of mid-arm circumference $(\mathrm{p}=0.193)$, in contrast with the literature that evaluated Japanese elderly (15). We attribute this to the fact that these measurements can vary in populations, and should be modified for the specific population that was conducted.

As a conclusion, although malnourished patients were detected, the number of well-nourished patients were higher. Therefore, it could be said that patients with heart failure are conscious of their health and diet. It is crucial for the health care providers to give advices on healthy living and nutrition to keep this elderly population well-nourished.

Ethics Committee Approval: This study was approved by the Scientific Researches Committee of Trakya University School of Medicine.

Informed Consent: Written informed consent was obtained from the participants of this study.

Conflict of Interest: The authors declared no conflict of interest.

Author contributions: Consept: IIIÖ, BK, BS, FMU. Design: IİÖ, BK, BS, FMU. Supervision: IİÖ, BK, BS, FMU Resources: IIIÖ, BK, BS, FMU. Materials: IİÖ, BK, BS, FMU. Data collection and/or processing: IİÖ, BK, BS, FMU. Analysis and/or interpretation: IİÖ, BK, BS, FMU. Literature search: IİÖ, BK, BS, FMU. Writing manuscript: IİÖ, BK, BS, FMU. Critical rewievs: IIIÖ, BK, BS, FMU.

Financial disclosure: The authors declared that this study received no financial support.

Editor-in-chief's Note: Three authors of this article, Irmak İrem Özyiğit, Beliz Koçyiğit, Begüm Söyleyici are members of the editorial board of Turkish Medical Student Journal. However, they did not take place in any stage on the editorial decision of the manuscript. The editors who evaluated this manuscript are from other institutions. 


\section{REFERENCES}

1. Tanai E, Frantz S. Pathophysiology of heart failure. Compr Physiol 2015;6(1):187-214.

2. Bloom MW, Greenberg B, Jaarsma T et al. Heart failure with reduced ejection fraction. Nat Rev Dis Primers 2017;3:17058.

3. Metra M, Teerlink JR. Heart failure. Lancet 2017;390(10106):1981-95.

4. Mosterd A, Hoes AW. Clinical epidemiology of heart failure. Heart 2007;93(9):1137-46.

5. McMurray JJV. Systolic HF. New Engl J Med 2010;362(3):228-38.

6. World Health Organization. Malnutrition definition. Cited 2019 Jan. Available from: URL: https://www. who.int/news-room/fact-sheets/detail/malnutrition.

7. Yoshihisa A, Kanno Y, Watanabe S et al. Impact of nutritional indices on mortality in patients with heart failure. Open Heart 2018;5(1):1-8.

8. Jacobsson A, Pihl-Lindgren E, Fridlund B. Malnutrition in patients suffering from chronic heart failure; the nurse's care. Eur J Heart Fail 2001;3(4):449-56.

9. Sciatti E, Lombardi C, Ravera A et al. Nutritional deficiency in patients with heart failure. Nutrients 2016;8(7):442.

10. Rahman A, Jafry S, Jeejeebhoy K et al. Malnutrition and cachexia in heart failure. Jpen-Parenter Enter 2016;40(4):475-86.

11. Guigoz Y. The mini-nutritional assessment $\left(\mathrm{MNA}^{\circ}\right)$ review of the literature - what does it tell us? J Nutr Health Aging 2006;10:66-87.

12. Yılmaz S, Miray Koç E, Kunduracı E et al. Kardiyoloji polikliniğine ayaktan başvuran hastalar ile kardiyoloji servisinde yatan hastaların beslenme durumlarının mini nütrisyonel değerlendirme testi ile karşılaştırılması. MN Kardiyoloji 2018;25(3):121-6.

13. Bonilla-Palomas JL, Gamez-Lopez AL, Anguita-Sanchez MP et al. Impact of malnutrition on longterm mortality in hospitalized patients with heart failure. Rev Esp Cardiol 2011;64(9):752-8.
14. Pyrgakis VN. Smoking and cardiovascular disease. Hellenic J Cardiol 2009;50:231-4.

15. Kuzuya M, Kanda S, Koike T et al. Evaluation of mini-nutritional assessment for japanese frail elderly. Nutrition 2005;21(4):498-503. 